\title{
STANISŁAW GRODŹ \\ Między poszukiwaniem porozumienia a błędnym kołem powrotu do konfliktów. Dialog międzyreligijny chrześcijan i muzułmanów
}

Niekiedy trudno się oprzeć wrażeniu, że historia kontaktów między chrześcijanami i muzułmanami zatacza pẹtlę i co pewien czas, jak zbłąkany wędrowiec, wraca w stare, utarte koleiny. Czy we wzajemnych kontaktach jesteśmy skazani jedynie na bląkanie się po bezdrożach i sięganie po rozwiązania silowe, tylko pozornie najskuteczniejsze i najprostsze? Czy narosłe przez wieki nieporozumienia, uprzedzenia i krzywdy tworzą balast tak ciężki, że nieuchronnie ciągnie on zarówno muzułmanów, jak i chrześcijan na dno nieustannych walk i klótni? Czy też może wspólnie dopracujemy się czasów, gdy wyznawcy obu religii będą starali się lepiej nawzajem rozumieć, okazywać sobie szacunek i wspomagać $w$ dzialaniach, mających na celu wychwalanie i pełnienie woli wszechmogącego Boga? W ciagu czternastu wieków wszelkie próby budowy porozumienia tonęly w odmętach rozpętywanych wojen i podsycania atmosfery wrogości. Do niedawna Kościól aktywnie wspóluczestniczyl w budowaniu wrogości wobec muzulmanów. Od czasu Soboru Watykańskiego II obserwować można jednak zmianę nastawienia Kościoła katolickiego nie tylko do wyznawców innych religii, ale także do samych tradycji religijnych. Także czlonkowie Światowej Rady Kościolów pracują nad zmianą własnego nastawienia do islamu i muzulmanów. Czy poszukiwanie trwałego porozumienia, a więc dialog międzyreligijny, leży poza możliwościami chrześcijan i muzulmanów? Czy też brakuje jedynie chęci? A może zbyt duże są zewnętrzne (pozareligijne) przeszkody?

Ostatnio, szczególnie w Europie Zachodniej, promuje się postrzeganie kontaktów chrześcijańsko-muzułmańskich jedynie pod kątem konfliktów. Nie jest to 
spojrzenie nowe i co jakiś czas staje się ono, niestety, dominujące. Należy jednak pamiętać, że zachodnioeuropejskie spojrzenie na kontakty między chrześcijanami i muzulmanami nie jest jedyne, choć usiłuje się czasem nadać mu charakter uniwersalny. Europejczycy z północno-zachodniej części kontynentu przez ostatnie dwieście lat kolonialnej dominacji w świecie narzucili własną perspektywę kontaktów z muzułmanami, które bardzo często były walką.

David Kerr, znawca historii kontaktów chrześcijańsko-muzulmańskich, zwraca uwagę na fakt, że zachodnioeuropejskie uporczywe postrzeganie islamu jako geopolitycznego problemu, który należy rozwiazzać siłowo, jest hiszpańskoportugalską spuścizna, wywodzącą się z czasów rekonkwisty ${ }^{1}$. Niestety, niektórzy chrześcijanie i muzułmanie ciagle nie potrafią wydostać się poza ten sposób patrzenia, który w znacznym stopniu stanowi kontynuację perspektywy kolonialnej. Chrześcijanie w innych regionach świata mają własną historię kontaktów $\mathrm{z}$ muzułmanami. Nie brak w niej momentów krwawych (a niektórzy chcą dostrzegać tylko takie), ale obfituje ona także w dosyć długie okresy wypełnione pokojową koegzystencją i twórczą rywalizacją. Nawet $w$ tak poszarpanych obecnie wojną regionach, jak na przykład Palestyna, starsi ludzie wspominają czasy, gdy sąsiedzi - wyznawcy różnych religii - zapraszali się wzajemnie na świętowanie religijnych świąt. Poszerzona perspektywa, niezbędna dla odkrycia różnorodności kontaktów muzułmańsko-chrześcijańskich, powinna zawierać głębsze spojrzenie na dialog międzyreligijny.

\section{Dialog międzyreligijny}

Zamierzam przyjrzeć się dialogowi międzyreligijnemu z perspektywy wzajemnych odniesień między chrześcijanami i muzułmanami. Oczywiście, w pewien sposób refleksja ta będzie dotyczyła relacji między wszystkimi religiami. Chociaż współcześnie używa się często sformułowania „dialog chrześcijańskomuzułmański", to uważam, że określenie to trzeba stosować z wielkim umiarem, rezerwując wyłącznie dla określenia takich kontaktów, w których obie strony starają się wzajemnie zrozumieć i poszukują najwyższego dobra. Konieczne wydaje się zatem znalezienie innego, nadrzędnego terminu.

\footnotetext{
${ }^{1}$ Muzułmanów z filipińskiej wyspy Mindanao Hiszpanie nazwali Moros (Maurowie) i zasto sowali przeciw nim znaną z wlasnego kraju strategię, czyli akcję zbrojną (D. Kerr: ChristianMuslim Relations: Lessons from History. W: M. Ip grave [ed.]: The Road Ahead. Londyn $2002 \mathrm{~s}$. $32-33,36)$
} 


\section{Zróżnicowanie terminologii}

Kontakty chrześcijańsko-muzułmańskie trwają od pierwszych lat formowania się muzulmańskiej wspólnoty religijnej. Wzajemne stosunki przybierały formę spotkań, zderzeń i wspólpracy, ocierając się niekiedy nawet o pewną formę dialogu międzyreligijnego ${ }^{2}$. Dialog ten nie jest tym samym, co współpraca, mająca na celu głównie znalezienie praktycznych sposobów rozwiązywania problemów, trapiących zarówno chrześcijan, jak i muzułmanów. Dialog ten nie jest także tym samym, co spotkania, które mogą ograniczać się do życzliwego realizowania dobrosasiedzkich stosunków. Współpraca i spotkania nie wyczerpuja bowiem tego dialogu. Liczne zaś zderzenia między muzułmanami i chrześcijanami trudno traktować jako przejawy dialogu. Wydaje się zatem, że termin „kontakty" jest wlaściwszy jako termin nadrzędny. Ogarnia on swoim zakresem zarówno dialog, jak i współpracę, spotkania, jak i zderzenia. Przez te ostatnie rozumiem walkę zbrojną oraz pisemne lub ustne polemiczno-apologetyczne starcia między chrześcijanami i muzułmanami. Zderzenia, chociaż liczne w historii wzajemnych kontaktów, oczywiście nie są w nią wpisane jako nieuniknione. Starcia często nie wypływały z różnicy religii, lecz wywoływane były głównie przez czynniki polityczne i ekonomiczne (czyli walkę o wladzę i dostęp do zasobów materialnych).

\section{Popularność dialogu}

W ostatnich dziesięcioleciach pojęcie „dialog” znacząco zyskało na popularności. Mówi się o konieczności stosowania postawy dialogu we wszystkich możliwych sytuacjach: od relacji w ramach rodziny przez kontakty między przedstawicielami różnych grup społecznych i instytucji działających w państwie aż po relacje międzynarodowe i międzykulturowe. Używa się tego pojęcia $z$ ogromną łatwością, gdyż współcześnie jesteśmy bardziej skłonni (przynajmniej teoretycznie) do rozwiązywania problemów i sporów bez używania przemocy, a przy tym rażą nas wszelkie autorytarne postawy. W popularnym rozumieniu dialog jest najczęściej pojmowany jako rozmowa czy debata, w wyniku której dochodzi się do ustalenia wspólnego stanowiska w danej kwestii. W taki sposób definiują go także słowniki ${ }^{3}$. To wspólne stanowisko rozumie się jednak zazwyczaj jako zgodę wszystkich stron na jedno, konkretne rozwiązanie osiągnięte na

\footnotetext{
${ }^{2}$ Można by tu jako przykład podać debatę między kalifem Al-Mahdim i nestoriańskim patriarchą Tymoteuszem I pod koniec VIII w. (zob. R. Caspar: Les versions arabes du dialogue entre le catholicos Timothee I et le caliphe al-Mahdi. "Islamochristiana”. T. 3: 1977 s. 107-175). Z drugiej strony Tymoteuszowi zarzuca się zbytnio teoretyczną refleksję, bez konkretnych odniesień do życia codziennego (zob. J. M. Gaudeu: Encounters and Clashes. Islam and Christianity in History. Vol. I. A Survey. Rzym 1990 s. 36).

${ }^{3}$ Stownik wspótczesnego języka polskiego. T. 1. Warszawa 1998 s. 171.
} 
drodze negocjacji, w trakcie których wszystkie strony poszly na pewne ustępstwa. Jest to zrozumiałe i akceptowane. Problem pojawia się wtedy, gdy takie pojęcie dialogu zostanie przeniesione na różne dziedziny życia jako „pojęciewytrych". Wyraźnym tego przykładem jest sfera kontaktów międzyreligijnych.

\section{Dialog międzyreligijny - inna kategoria dialogu}

W kontekście kontaktów międzyreligijnych potoczne rozumienie dialogu jako procesu negocjacyjnego bardzo utrudnia i wypacza pojmowanie ich istoty. Wielu ludziom dialog międzyreligijny kojarzy się bowiem z negocjowaniem wspólnego stanowiska, czyli rozmywaniem granic w imię jakiejś poprawności politycznej, lub ograniczaniem się tylko do poszukiwania elementów wspólnych z pomijaniem różnic. Sytuację określaną jako „dialog chrześcijańsko-muzułmański” przedstawia dziennikarz „Der Spiegel” Jochen Bölsche, którego tekst pod polskim tytułem „Dialog zaklamany” przedrukowano w „Tygodniku Powszechnym”. Bölsche stara się ukazać, że z jednej strony Kościoły chrześcijańskie w Niemczech (a przynajmniej niektórzy ich przedstawiciele) upatrują w dialogu panaceum na każdy problem, lecz jednocześnie dialog z muzułmanami obserwuje się ze szczególnq nieufnościq i mnożq się wątpliwości, czy niekiedy dialog ten nie jest prowadzony ze strony chrześcijańskiej ze zbytniq ustępliwościq, jeśli nie wręcz naiwnościq ${ }^{4}$.

Chociaż tekst przedstawia jaką́ formę kontaktów chrześcijańsko-muzułmańskich, to nie można określić jej jako dialog międzyreligijny, bo w nim nie ma miejsca na „ustępliwość” czy „naiwność”. Zdaniem Józefa Urbana, znawcy zagadnień dialogu międzyreligijnego, problem ze zrozumieniem terminu „dialog" w jego teologicznym sensie wynika $z$ jego stosunkowej nowości w słownictwie teologicznym, a także z pewnej dewaluacji i zbanalizowania kategorii dialogu nie tylko $w$ popularnej świadomości, lecz także $w$ języku kościelnym $i$ teologicznym. Może wskazane byłoby zatem znalezienie innego niż „dialog” słowa na oznaczenie istoty kontaktów międzyreligijnych, gdyż nie chodzi w nich o negocjowanie swojego miejsca w świecie religijnego pluralizmu. Dialog międzyreligijny stanowi zupełnie odmienną kategorię dialogu.

Arabista Marek M. Dziekan nie używa terminu „dialog międzyreligijny”, ale omawia także kontakty, jakie zachodzą na płaszczyźnie religijnej. Zdaniem Dziekana mówienie o dialogu chrześcijańsko-muzulmańskim jest zwodnicze, gdyż jego zwolennicy opieraja go na wspólnych rzekomo dla obu religii plaszczyznach (np. wspólne źródła monoteistycznych religii, analogiczne elementy

${ }^{4}$ J. Bölsche: Dialog zakłamany. „Tygodnik Powszechny”. R. 2002 nr 5 (2743) s. 9. 173

J. Urban: Dialog miedzyreligijny w posoborowych dokumentach Kościoła. Opole 1999 s. 
dogmatyki i kultu). Tymczasem Dziekan wskazuje, że wyszukiwane zjawiska sa w obu religiach nazywane podobnie, lecz różne treściowo (hadżdż nie jest peregrynowaniem, salat nie jest rozmową z Bogiem, Isa ibn Miriam nie jest tożsamy z Jezusem Chrystusem, a pojęcie Boga nie zawiera tej samej treści). Dziekan mówi zatem o „dialogu zaklóconym”, którego uczestnicy, używając tych samych pojęć, w istocie się nie rozumieją. Dostrzegając wagę nawet najmniejszych prób nawiązania prawdziwego kontaktu międzykulturowego, Dziekan upatruje przyszłość kontaktów między „światem islamu a cywilizacją zachodnią przede wszystkim w tolerancji związanej ze wzajemnym szacunkiem, ale nie w dialogu. Dziekan rozumie zatem dialog jako próbę sil, debatę lub walkę na argumenty, w której obie strony zakładają swoją kulturową wyższość nad przeciwnikiem i starają się przekonać go do przyjęcia swoich racji, wymuszając na nim także zmianę religijnej afiliacji. Takie rozumienie dialogu można by wywnioskować z konkluzji artykułu Dziekana ${ }^{7}$.

Jednym z najbardziej systematycznych opracowań zagadnień związanych z dialogiem międzyreligijnym jest dokument Papieskiej Rady do Spraw Dialogu Międzyreligijnego i Kongregacji Ewangelizacji Ludów z 1991 r. pt. „Dialog i przepowiadanie" ${ }^{8}$. Dostrzegając wieloznaczność pojęcia „dialog”, autorzy dokumentu precyzują, że będą go używali w następującym znaczeniu: (..) w kontekście pluralizmu religijnego termin dialog znaczy »całokształt pozytywnych $i$ konstruktywnych stosunków międzynarodowych $z$ osobami i wspólnotami innych religii majacych na celu wzajemne poznanie i obopólne ubogacenie« (D\&M 3) pozostajac jednak wiernym prawdzie i respektując wolność każdego. Implikuje on też świadectwo i pogłębienie swych przekonań religijnych (D\&P 9).

Dialog międzyreligijny charakteryzuje się oczyszczaniem spojrzenia przez odrzucanie uprzedzeń, nawracaniem się do Boga wszystkich zaangażowanych weń uczestników oraz wzbogacaniem własnej wiary przez odkrywanie dotąd niezauważanych sposobów Bożej obecności i Bożego działania we wlasnej tra-

${ }^{6}$ M. M. Dziekan: Spotkanie i konfrontacja. Kultura zachodnia i świat islamu. „Studia Bobolanum". T. 1: 2003 s. 10. Krytykowane przez Dziekana podejście opisuje np. Ł. Kamyk owski: Dialog. 4. Dialog międzyreligıjny. W: M. Rusecki i in. (red.): Leksykon teologii fundamentalnej. Lublin-Kraków 2002 s. 314.

${ }^{7}$ W odniesieniu do tolerancji związanej ze wzajemnym szacunkiem Dziekan stwierdza: $Z$ tym, niestety, zarówno z jednej jak i z drugiej strony jest bardzo źle (M. M. Dziekan: Spotkania i konfrontacja, dz. cyt., s. 6, 11).

${ }^{8}$ Dialog i przepowiadanie. Tekst polski - „Nurt SVD”. R. 27: 1993 nr 3 (62) s. 75-106. Odniesienia do dokumentu w dalszej części artykułu będą oznaczane skrótem „D\&P”. Skrót „D\&M” oznacza dokument watykańskiego Sekretariatu dla Niechrześcijan zatytułowany: Postawa Kościoła wobec wyznawców innych religii. Refleksje i wskazówki dotyczqce dialogu i misji W: W. Chrostowski, R. Rubinkiewicz (opr.): Żydzi i judaizm w dokumentach Kościoła i nauczaniu Jana Pawla II (1965-1989). Warszawa 1990 s. $44-59$. 
dycji religijnej oraz poza nią ${ }^{9}$. Nie szuka się zatem wspólnego stanowiska ani nie naklania się partnerów do przyjęcia jednego poglądu i sposobu wierzenia w Boga, ale, dając świadectwo własnej wierze i oddaniu się Bogu, dąży się do odkrywania tego, jak Bóg działa w innych i poprzez innych ludzi. Towarzyszy temu przekonanie, że Bóg w sobie znany sposób doprowadza ludzi do zbawie$\mathrm{nia}^{10}$.

Przyjęcie jednego zbawczego zamiaru Boga wobec całej ludzkości zakłada jedność wszystkich ludzi na plaszczyźnie religijnej ${ }^{11}$. Skoro wierzymy, że istnieje jeden Bóg i że pragnie On zbawienia wszystkich ludzi, to musimy przyjąć, że ten sam Bóg przemawia w sercach obu partnerów dialogu, ten sam Duch ich łqczy. Ten sam Bóg wzywa i kieruje rozmówców ku nim samym, dzięki ich wzajemnemu świadectwu. W ten sposób stajq się oni dla siebie nawzajem znakiem, który prowadzi do Boga ${ }^{12}$. Jeśli Duch Święty formuje inne religie i kultury, jednocząc je i przygotowując na przyjęcie Ewangelii, to wejście w dialog z niechrześcijanami oznacza możliwość uczenia się od nich czegoś ważnego także w wymiarze życia duchowego. W tej perspektywie istnieje możliwość dialogu międzyreligijnego, czyli takiego w którym chrześcijanin nie rezygnuje z wlasnych przekonań o powszechności misji Chrystusa i Kościoła ${ }^{13}$.

${ }^{9}$ Ł. Kamykowski: Dialog, dz. cyt., s. $313-314$.

${ }^{10} \mathrm{~W}$ relacji z sympozjum „Spotkanie z islamem”, które odbyło się w Papieskim Wydziale Teologicznym „Bobolanum” w Warszawie w dniu 28 listopada 2002 r., reporter KAI napisał, że w dyskusji panelowej stwierdziłem: nie należy mówić o dialogu międzyreligtjnym, ale o kontaktach z islamem, gdyż dialog zakłada dojście do porozumienia. („Wiadomości KAI” [8 grudnia 2002] s. 5). Trudno się spierać, gdyż nie dysponuję nagraniem wypowiedzi, ale w takim ujęciu zawarty jest zbyt duży skrót myślowy, który sugeruje, że dialog międzyreligijny zakłada dojście do porozumie nia. Tymczasem jeśli „porozumienie” oznacza „wspólne stanowisko”, to tego właśnie dialog międzyreligijny nie zakłada. Relacja z tego samego sympozjum umieszczona na internetowym portalu www.arabia.pl przedstawia moją wypowiedź inaczej i pod nią podpisuję się bez wahania: celem takiego dialogu nie ma być rezygnacja z wlasnych przekonań i przejęcie przekonań drugiej strony. Celem jest kontakt, możliwość spotkania $z$ drugim czlowiekiem bez apriorycznego oceniania go, bez gotowych przesqdów i stereotypów (http://www.arabia.pl/article.php?id=1345).

${ }^{11}$ Przychodzą tu na myśl słowa Jana Pawła II na temat modlitwy o pokój w Asyżu w 1986 r.: Istnieje zatem tylko jeden plan Boży dla każdej istoty ludzkiej, która przychodzi na ten świat [...]. Plan Boży, jedyny i ostateczny, ma swoje centrum $w$ Jezusie Chrystusie, Bogu i człowieku «w którym ludzie znajjuja pelnię życia religijnego i w którym Bóg wszystko z soba pojednal» (Nostra aetate, 2). [...] Ta wlaśnie pełna blasku tajemnica jedności rodzaju ludzkiego sięgajaca jego stworzenia i zarazem tajemnica jedności zbawczego dziela Chrystusa, które przyniosło ze sobq narodziny Kościola jako szafarza i narzędzia - ujawnila się w sposób wyraźny w Asyżu, pomimo istnienia nie tajonych bynajmniej czy lagodzonych różnic wyznaniowych" (Jan Paweł II: To, co powinno stać sie kontynuacja spotkania w Asyżu. Przemówienie do Kurii Rzymskiej 22 XII $1986 \mathrm{r}$. „L'Osservatore Romano”. Wydanie polskie. R. 7: 1986 nr 11-12 s. 15).

${ }^{12}$ J. Dupuis: Dialog międzyreligijny w spoleczeństwie wieloreligijnym. „Życie Duchowe”. R. $2000 \mathrm{nr} 24$ s. 64.

${ }^{13}$ Ł. Kamykowski: Dialog, dz. cyt., s. 314. 
W cytowanym już watykańskim dokumencie ujęte jest to chyba jeszcze wyraźniej: W tym dialogu zbawienia wszyscy, chrześcıjanie i niechrześcijanie, sq wezwani do wspólpracy z Duchem Pana zmartwychwstałego. Duchem, który jest powszechnie obecny i działa. Dialog międzyreligijny nie chce osiagnqć tylko obopólnego zrozumienia i nawiqzania stosunków przyjacielskich. Dochodzi on do poziomu dużo głębszego, do poziomu samego ducha, gdzie wymiana i dzielenie polegajq na wspólnym świadectwie o tym, w co każdy wierzy, i na wspólnym odkrywaniu wzajemnych przekonán religijnych. Przez dialog chrześcijanie $i$ niechrześcijanie sq zaproszeni, aby pogłębic wymiary religijne ich zaangażowania $i$ odpowiedzieć z rosnqcq uczciwościq na osobiste wezwanie Boga i na darmowy dar, w którym daje się On sam, dar, który przechodzi zawsze, jak mówi nasza wiara, przez pośrednictwo Jezusa Chrystusa i dzieło jego Ducha (D\&P $40)$.

Czy zatem krytycy dialogu międzyreligijnego, obecni zarówno w środowiskach muzułmańskich jak i chrześcijańskich, krytykują takie rozumienie dialogu międzyreligijnego? Wydaje się, że ich krytyka dotyczy raczej różnych wypaczeń, które świadomie lub nieświadomie nazywane są dialogiem międzyreligijnym. Wspólne chrześcijańskim i muzułmańskim krytykom wydają się być: zarzut rzekomego zacierania granic między religiami przez dialog międzyreligijny, podejrzenie o irenizm i oskarżenie, iż dialogiem zajmuja się ludzie słabi w swojej wierze, wątpiący ${ }^{14}$. W zarzutach tych zawiera się ukryta obawa przed utratą własnej pozycji, ale także obawa przed wyruszeniem w podróż w nieznane $\mathrm{z}$ wyznawcami obcej religii, po których nie wiadomo czego można się spodziewać. Przebija w tym wyraźnie nieznajomość przynajmniej podstaw zarówno islamu wśród chrześcijan, jak i chrześcijaństwa wśród muzułmanów. Chrześcijańscy krytycy postrzegają dialog międzyreligijny jako ukryta promocję religii pozachrześcijańskich i starają się eksponować przykłady uzasadniające stawianą przez nich tezę, a mianowicie że wyznawcy innych religii nie są zainteresowani żadnym dialogiem, a wręcz zdecydowanie go odrzucają i negują ${ }^{15}$. Z kolei krytycy muzułmańscy dopatrują się $w$ dialogu międzyreligijnym przykrywki dla kontynuacji chrześcijańskiej działalności misyjnej. Ta ostatnia jest bacznie obserwowana także przez muzułmanów życzliwie odnoszących się do chrześcijań-

${ }^{14}$ E. Renaud: Le dialogue islamo-chrétien vu par les musulmans. „Islamochristiana”. T. 23: 1997 s. $121,123,131-132$.

${ }^{15}$ Zob. np. H. van Straelen: L'Eglise et les religions non chrétiennes au seuil du XXIe siècle. Etude historique et théologique. Paryż 1994 s. 49 -56, oraz s. $1-3,301-307,311$-312. Sytuację komplikują także głosy, które promując dialog międzyreligijny, jakby całą zasługę z tym związaną przypisują wyłącznie chrześcijanom (E. Sakowicz: Trudny dialog Kościoła z islamem. „Collectanea Theologica”. R. 71: $2001 \mathrm{nr} 2$ s. 116. 
stwa i chrześcijan, a wszelkie nadużycia czy próby wykorzystania okazji dla uprawiania prozelityzmu sa zdecydowanie krytykowane ${ }^{16}$.

\section{Dialog a misja}

Wprowadzenie pojęcia dialogu do oficjalnego nauczania Kościoła katolickiego od czasów Soboru Watykańskiego II spowodowało także zwrócenie większej uwagi na misję. Negocjacyjne pojmowanie dialogu połączone z koniecznością dokonania nowej oceny misji (dotychczasowe dwa glówne motywy działalności misyjnej - „nawracanie dusz" i zakładanie Kościoła - stracily swoją siłę oddziaływania) doprowadziło do sytuacji, którą amerykański misjolog katolicki Robert Schreiter nazwal „okresem kryzysu misyjnego" ${ }^{17}$. W kościelnych dokumentach „misyjny refren” zaczął zatem towarzyszyć wszelkim fragmentom dotyczacym dialogu: „Dialog owszem, ale nie możemy zapominać o misji”. Można by w tym dopatrywać się rozwinięcia stanowiska zawartego w soborowym Dekrecie o działalności misyjnej Kościoła Ad gentes (DM). Wystarczająco jasnemu przedstawieniu zamysłu, jaki przyświeca dialogowi, towarzyszy przypominanie o konieczności głoszenia Chrystusa i podkreślanie niemożności zastapienia tego ostatniego przez dialog ${ }^{18}$. W moim przekonaniu napięcie istniejące między rozumieniem dialogu i misji, szczególnie $\mathrm{w}$ dokumentach Kościola katolickiego, wypływa $z$ niezrozumienia sensu dialogu międzyreligijnego. Wydaje się bowiem, że wspomniane już negocjacyjno-przetargowe pojmowanie dialogu wyraźnie oddziałuje na niektórych teologów.

Dopiero watykański dokument z 1991 r. wyjaśnia relację między dialogiem, przepowiadaniem i misja w sposób - jak dotąd - najbardziej klarowny ${ }^{19}$ : zarówno dialog międzyreligijny jak i przepowiadanie, mimo że nie sq na tej samej

${ }^{16}$ E. Renaud: Le dialogue islamo-chretien, dz. cyt., s. $129-135$.

${ }^{17}$ R. J. Schreiter: Changes in Roman Catholic Attitudes toward Proselytism and Mission. W: J. A. Scherer, S. B. Bevans (eds.): New Directions in Mission and Evangelization. Vol. 2. Maryknoll 1994 s. $120-121$.

${ }^{18}$ DM 11 w tekście opatrzonym tytułem „Świadectwo chrześcijańskie” bardzo wyraźnie nakreśla postawę i praktykę dialogu międzyreligijnego, choć nie używa tego terminu. Jednak podkreślenie w DM 13 konieczności „mówienia o tajemnicy Chrystusowej” tam gdzie warunki ku temu sq sprzyjające, stwarza wrażenie jakby autorzy tekstu pojmowali chrześcijańskie świadectwo wylącznie jako milcząca i "gettowa” obecność chrześcijan w społeczności niechrześcijan. Czy dla zaangażowanego chrześcijanina nie jest samo w sobie zrozumiałe, że $w$ sytuacjach sprzyjajacych będzie także słownie dzielił się swoją wiarą ze swoimi nie-chrześcijańskimi bliźnimi?

${ }^{19}$ Zastanawiające jest to, że wielu autorów częściej skupia swoją uwagę wyłącznie na Encyklice Redemptoris missio (55-57), pozostawiając w cieniu watykański dokument Dialog i przepowiadanie. Tymczasem dokument ten uszczegóławia niejako zagadnienie wzajemnej relacji dialogu międzyreligijnego, przepowiadania i misji - zob. J. Dupuis: A Theological Commentary: Dialogue and Proclamation. W: W. R. Burrows (ed.): Redemption and Dialogue. Reading Redemptoris missio and Dialogue and Proclamation. Maryknoll 1994 s. 119 -158. 
płaszczyźnie, stanowiq autentyczne elementy misji ewangelizacyjnej Kościoła. Oba sq prawowite i konieczne. Sq ściśle powiqzane, ale nie zamienialne: prawdziwy dialog międzyreligijny zakłada ze strony chrześcijan pragnienie, aby dać poznać i coraz bardziej przyczyniać się do pokochania Jezusa Chrystusa. Przepowiadanie Jezusa Chrystusa powinno zaś odbywać się w duchu ewangelicznego dialogu (D\&P 77).

Napięcia i nieporozumienia, związane z rozumieniem dialogu międzyreligijnego, wiążą się też w jakiś sposób ze sposobem czy sposobami pojmowania misji. Misyjny mandat, nadany uczniom przez Jezusa, nie został jedynie sformułowany w jego Mateuszowej wersji: Idźcie i nauczajcie (Mt 28, 19). Marek oddał to samo słowami: Idźcie na cały świat i głoście Ewangelię (Mk 16, 15), a Łukasz ujął to wyrażeniem: Wy jesteście świadkami tego (Łk 24, 48). Jednak, nawet jeśli będziemy trzymać się tylko sformułowania użytego przez Mateusza, to „nauczajcie” nie oznacza koniecznie „podporządkowujcie sobie”. Tak jak istnieją różne koncepcje nauczania, w tym na przykład taka, w której uczący jest także uczniem i uczy się sam od tych, których uczy, tak różne są koncepcje misji. W chrześcijańskiej tradycji świadectwo życia - a nie tylko świadectwo słowne - dawane swojej wierze w Chrystusa nie straciło swego znaczenia, choć często bywa spychane na margines dzialania przynoszącego szybkie (choć krótkotrwale) efekty.

Potrzeba jednak czasu, aby wygasła dawna koncepcja misji, podobnie jak nieporozumienia otaczające dialog. Papieskie nauczanie, podkreślając konieczność prowadzenia misji, skierowuje uwagę chrześcijan na bardziej „dialogiczny” sposób jej prowadzenia, który ma więcej wspólnego z dawaniem świadectwa niż $\mathrm{z}$ negocjacją. Rozwinięte $\mathrm{w}$ ostatnich stuleciach nieszczęśliwe utożsamienie nieomal misji z prozelityzmem nie zmieni się od razu. Za potrzebą takiej zmiany świadczy jednak np. wspólna wypowiedź Jana Pawla II i arcybiskupa Christodulosa na ateńskim Areopagu: Potępiamy wszelkie uciekanie się do przemocy, prozelityzmu i fanatyzmu $w$ imie religit ${ }^{20}$.

\section{Konieczność dialogu}

Kardynał Francis Arinze, długoletni przewodniczący Papieskiej Rady do Spraw Dialogu Międzyreligijnego, dostrzega konieczność dialogu międzyreligijnego, podając cztery powody przemawiające za jego intensyfikacją oraz cztery argumenty, które - jego zdaniem - czynią taki „dialogiczny” sposób działania czymś niezwykle istotnym. Wśród powodów tych wymienia:

- istniejacy w świecie pluralizm religijny i konieczność poważnego potraktowania go;

${ }^{20}$ „Wiadomości KAI” (13 maja 2001) s. 25. 
- wyrażaną przez wielu ludzi tęsknotę za urzeczywistnieniem jedności i wspótpracy;

- konieczność wspólnego stawiania czola niektórym większym problemom i wyzwaniom obecnym we współczesnym świecie (sprawiedliwość i pokój, AIDS, narkomania);

- przeciwstawianie się szerzącej się przemocy.

Wśród argumentów, przemawiających za dialogiem międzyreligijnym, Arinze wyliczyl: możliwość wzajemnego duchowego wzbogacenia się, a także fakt, iż dialog międzyreligijny pomaga wierzącym bardziej otwierać się na dzialanie Ducha Swiętego, uczy ich, w jaki sposób lepiej i wyraźniej przedstawić Chrystusa i chrześcijaństwo ludziom innych kultur i religii oraz ułatwia proces inkulturacji ${ }^{21}$.

Wspomniany już kilkakrotnie zamysł dialogu międzyreligijnego, którym jest glębsze nawrócenie wszystkich do Boga, bardzo trafnie i zwięźle ująl David Burrell we wstępie do książki znanego islamologa Rogera Arnaldeza pt. Three messengers for one God. Stwierdził on, że potrzeba nam wzajemnego zrozumienia i uznania, ale także krytycznego i samokrytycznego postrzegania problemu. Zamiast dążenia do wypracowywania czegoś wspólnego, mamy poszerzać nasze horyzonty w obliczu różnorodności. Celem nie jest jednak poszerzony schemat, ale wzbogacony poszukiwacz: odkrycie własnej wiary w spotkaniu wiary drugiego $^{22}$. Takie podejście do zagadnienia wydaje się być efektem wyciagnięcia wniosków z bezowocności wcześniejszych kontaktów i stwierdzenia, że polemiki kończą się w ślepym zaułku. Tam również prowadzą wysiłki podejmowane w celu poszukiwania plaszczyzn obu religiom wspólnych, jeśli przyświeca im zabarwiony irenizmem lub synkretyzmem zamiar.

Wspomniany przez Burrella „wzbogacony poszukiwacz” przywodzi na myśl rolę Kościoła, którą cytowany już watykański dokument ujmuje następująco: (...) posłannictwo Kościoła skierowane jest do wszystkich ludzi. Można uważać, że w dialogu ma ono role profetycznq w stosunku do religii, do których ludzie należq. Dajq̨ śswiadectwo wartościom ewangelicznym, stawia pytanie tym religiom. $W$ takim samym stopniu, w jakim nosi ono znamię ograniczeń ludzkich, Kościót również może zostać zakwestionowany. Przez fakt promowania tych wartości, w duchu zdrowego współzawodnictwa i respektu dla misterium Boga, członkowie Kościoła i członkowie innych religii uznajq siebie za towarzyszy wspólnej drogi, do podjęcia której wezwana jest cała ludzkość. Papiez Jan Paweł II powiedział

${ }^{21}$ F. A r i n z e: Interreligious Dialogue in the Third Millennium. „Studia Missionalia”. T. 48: 1999 s. 203-214.

${ }^{22}$ D. B u r r e 1 l: Wstep. W: R. A r n a 1 d e z: Three messengers for one God. Notre Dame. Londyn 1994 s. VII. 
w Asyżu, na koniec Dnia Modlitw, Postu i Pielgrzymki o pokój: »Dostrzeż w tym antycypacje tego, co chciałby Bóg, aby się zrealizowało w historii ludzkości: braterskie wędrowanie, w którym towarzyszymy sobie wspólnie, w kierunku pewnego celu transcendentnego, który Bóg dla nas przygotował $(\mathrm{D} \& \mathrm{P} 79)^{23}$.

Czyż podobnej myśli nie wyraża koraniczny weset (5:48): Dla każdego $z$ was uczyniliśmy norme i droge otwarta. A gdyby Bóg zechciał, to uczynitby was jednym narodem, lecz [jego planem jest], żeby was doświadczyć w tym, co wam dał. Starajcie się więc pilnie czynić dobre dzieła. Do Boga powrócicie wszyscy razem. On obwieści wam to, w czym się rớżniliście ${ }^{24}$.

Jego echa znajduję także w wypowiedziach niektórych teologów i religioznawców. Po ukazaniu jak bardzo odmienne jest pojmowanie Jezusa przez chrześcijan i muzulmanów, Peter Antes, prezydent International Association for the History of Religion, podkreślił wage kontynuowania dialogu dla pokojowego współistnienia chrześcijan i muzułmanów. Wystapienie swoje zakończył długim cytatem z dzieła M. Bauschkego o Jezusie: Uczestnicy każdej ziemskiej polemiki, której obiektem jest Jezus - niezależnie od tego, czy ma ona miejsce w samym chrześcıjaństwie, czy w dialogu (żydowsko)-chrześcıjańsko-islamskim - powinni pamię tać o jednym: tylko Jeden jedyny bę dzie mógł u kresu czasów powiedzieć $i$ powie, jak dalece Jezus jest Chrystusem Boga, oraz czy i w jakim stopniu ludzkie pojmowanie Jezusa było nieporozumieniem czy błędnq interpretacjq. Wszelka ludzka chrystologia ma, mimo swej tymczasowości i niedoskonałości i wbrew nim, służyć Bogu. W swych rớznorakich chrześcıjańskich i islamskich formach jest ona i pozostanie chrystologiq »ad maiorem Dei gloriam (FIp 2, 11) «

\section{Nieuchronność konfliktów?}

Mimo obaw i sceptycyzmu wobec dialogu międzyreligijnego, a także trudności z jego właściwym zrozumieniem, tylko on stwarza szansę wyrwania się $z$ błędnego koła ciagłych nawrotów do, kończących się zderzeniami, konfliktów w kontaktach chrześcijańsko-muzułmańskich. Zderzenia bowiem nie stanowią niezbędnego elementu wzajemnych relacji. Smutkiem napawa istnienie tendencji do

\footnotetext{
${ }^{23}$ Często dopiero w zetknięciu z tym, co inne wyraźniej widzimy własne niedoskonałości. Kościól traci swą przejrzystość jako sakrament zbawienia przez niedoskonałość swoich członków i dlatego również jako instytucja doświadcza stałej potrzeby reformy $i$ odnowy (D\&P 36, 41; RMis $56)$.

${ }^{24}$ Koran. Tłum. J. Bielawski. Warszawa 1986.

${ }^{25}$ P. Antes: Jezus Chrystus w ocenie islamu. W: M. Rusecki i in. (red.): Chrześcijaństwo jutra. Lublin 2001 s. 719.
} 
tworzenia „konfliktu bezprzedmiotowego", jak nazywa go M. Dziekan, konfliktu, który bazuje na zwyczajnym przekonaniu, że inność drugiego wywoluje jedynie agresję (ponieważ nie znam i nie rozumiem drugiego, i boję się go, więc wnioskuję, że stanowi on dla mnie zagrożenie). Dziekan wskazuje, że fakt wpadania w pulapkę mechanicznego przenoszenia i przypisywania sobie nawzajem wrogich intencji jest częsty zarówno u ludzi wyrosłych w kulturze Zachodu, jak i u muzułmanów ${ }^{26}$. Słaba znajomość religii i sytuacji społeczno-politycznej strony przeciwnej ciagle sprawia, że strona ta jest fałszywie postrzegana jako kulturowy i religijny monolit (tak widzi chrześcijaństwo wielu muzułmanów i tak postrzega islam wielu chrześcijan).

W ostatnim dziesięcioleciu XX w. ogromne zainteresowanie wywołała propagowana przez Samuela Huntingtona teoria zderzeń między cywilizacjami ${ }^{27}$. Zderzenia te mają być nieuchronne, a aktualnie istotnym jest konflikt między Zachodem a światem islamu. Huntington ma swoich odpowiedników wśród muzułmanów. Jednym z nich jest zmarły w 1996 r. Kalim Siddiqui, założyciel londyńskiego Muslim Institute ${ }^{28}$. Zdaniem Abdelaziza Testasa z chińskiego Nanjing University of Economics glówne tezy Siddiqui' ego i Huntingtona w istocie się nie różnią się. Podejście obu polega na dokonaniu wybiórczej analizy sytuacji w świecie z zamiarem wyraźnego przeciwstawienia sobie różnych cywilizacji. Istotna jest przynależność kulturowa, w której element religijny odgrywa znaczaccą rolę. Zarówno model Huntingtona, jak i Siddiqui' ego, wywołują podobne reakcje: paranoję i wrogość. Uproszczony podział świata, dokonany jedynie na bazie elementów kulturowych, wzbudza lęk i podejrzliwość, które przejawiaja się w mentalności „my-przeciw-wam”. Przez podejrzliwość zakłócone zostaje poczucie bezpieczeństwa, a przy tym wytwarza się wrogość i gniew skierowane przeciw tym, których postrzega się jako zagrożenie. Testas przypomina, że większość konfliktów opartych na różnicach kulturowych potrzebuje trzech warunków do ich wywołania: politycznych agitatorów, odpowiedniej retoryki i pojawienia się sprzyjających okoliczności. Agitatorzy mobilizują grupę ludzi o jasno określonej wspólnej tożsamości oraz świadomości pokrzywdzenia i towarzyszących im kategorycznych żądań. W ten sposób powstaje mechanizm, który działa przy zaistnieniu sprzyjających okoliczności. Łatwość, z jaką mechanizm ten się uaktywnia, Testas obrazuje, podając przykład fałszywego przekonania, przypisu-

${ }^{26}$ M. M. Dziekan: Spotkanie i konfrontacja, dz. cyt., s. 5-6.

${ }^{27}$ S. P. Hunting ton: Zderzenie cywilizacji i nowy ksztalt ladu światowego. Warszawa 1998. Pierwotna teza została przedstawiona w artykule Clash of Civilizations? „Foreign Affairs” 1993. Tekst polski: Wojna cywilizacji? "Res Publica Nowa”. R. 1994 nr 2 (65). J. Danecki zwraca uwagę, iż podobne poglądy głosił swego czasu L. Kołakowski, utrzymując, iż kultury nie moga być wobec siebie tolerancyjne (zob. J. Danecki: $O$ granicach dialogu $z$ islamem. http://www.arabia.pl/article.php?id=676).

${ }^{28}$ Więcej na temat Kalima Siddiqui - zob. http://www.islamicthought.org/ks-home.html 
jącego zamach bombowy w Oklahoma City w 1995 r. muzułmanom, które rozpowszechniło się przed zakończeniem oficjalnego dochodzenia ${ }^{29}$.

Trzeba też pamiętać, że w międzykulturowych konfliktach znaczną rolę odgrywają elementy nie należące do sfery cywilizacji, z których najważniejszym jest ekonomia. Analizy wykazuja, że wybuch wojny może zostać spowodowany np. obawami strat w międzynarodowym handlu ${ }^{30}$. Ogromne znaczenie ma także sposób przedstawiania konfliktów przez środki społecznego przekazu. $W$ doniesieniach z indonezyjskich Moluków sprzed kilku lat ciagle mówiono o walkach między chrześcijanami i muzułmanami. Faktem jest, że wyznawcy obu religii walczyli ze soba, jednak konflikt mial inne niż religijne podłoże. Zwiększona imigracja z Sulawesi (Celebes) zachwiala społeczno-ekonomiczną struktura od stuleci funkcjonującą na Molukach. Wcześniej protestanci w większości kontrolowali urzędy i szkolnictwo, a handel leżał w rękach muzułmanów. Agresywny kapitalizm ostatnich lat wzbogacił muzułmańskich kupców, a wepchnął w trudności ekonomiczne lokalnych rolników, w większości chrześcijan. Wzmocnieni liczebnie i ekonomicznie muzułmanie podjęli próbę wyzwolenia się spod czegoś, co postrzegali jako protestancką dominację. Zatem zmagania, które przerodzily się, niestety, w krwawe rozruchy, przez muzułmanów były traktowane jako walka o wyzwolenie, podczas gdy dla protestantów byly próbą odzyskania znaczacej pozycji, z której czuli się spychani przez wpływowych kupców-przybyszów ${ }^{31}$. Z relacji prezentowanych w polskich mediach odnosiło się tymczasem wrażenie, że na Molukach trwa wojna religijna.

Chociaż wielu molukańskich katolików przyłączyło się do protestanckich bojówek, to niewielka liczebnie wspólnota katolicka zdołała zachować neutralność, podejmując działania na rzecz pojednania. Zaczęły także powstawać spoleczne organizacje, grupujące przedstawicieli wszystkich religii, które to organizacje, pomagając poszkodowanym, wyrażały otwarcie sprzeciw wobec trwającej wojny domowej. Opisując całą sytuację John Prior, misjonarz od wielu lat związany $z$ indonezyjskimi środowiskami naukowymi, stwierdza, że w efekcie zbrodnicza zmowa niektórych polityków z Dżakarty, wojskowych dowódców i religijnych ekstremistów niejako zmusiła muzułmanów i chrześcijan do wyjścia ponad to, co jedynie zewnętrzne - przepisów, budynków, rytuałów - i odrodzenia się jako wzajemnie szanujących się wspólnot, zdolnych dostrzegać w twarzy ofiar

${ }^{29}$ A. Testas: Models of Cultural Exclusion and Civilizational Clashes: A comparison between Huntington and Siddiqui. "Islam and Christian-Muslim Relations". R. 14: $2003 \mathrm{nr} 2 \mathrm{~s}$. $179-180$.

${ }^{30}$ Dotyczy to także sytuacji w ramach jednej cywilizacji (A. Testas: Models of Cultural ExcIusion and Civilizational Clashes, dz. cyt., s. 185).

${ }^{31}$ J. Prior: Evil abroad in Ambon. ,The Tablet” (20 January 2001) s. 76. 
oblicze Boga ${ }^{32}$. Niedawno pojawily się $\mathrm{w}$ mediach doniesienia $\mathrm{z}$ Moluków, stwierdzające, że przywódcy religijni różnych wspólnot wyraźnie mówią o instrumentalnym posługiwaniu się religią przez różne grupy w celu zrealizowania wlasnych politycznych i ekonomicznych interesów ${ }^{33}$.

Istotną sprawą $w$ kontaktach międzykulturowych (w tym: międzyreligijnych) jest umiejętność określania własnej tożsamości. Klopoty wynikaja z tego, że - zdaniem takich politologów jak Huntington - wielu ludzi tworzy swą tożsamość jedynie w sposób negatywny, w opozycji do innych i w oparciu o różnice, a nie o to, co wspólne ${ }^{34}$. Wielu chrześcijan postępuje w podobny sposób. Tymczasem Jan Paweł II zwrócił uwagę na fakt, że chrześcijańska tożsamość nie wyraża się $w$ opozycji do innych, lecz $w$ zdolności wyrzeczenia się siebie $i$ wychodzenia naprzeciw braciom. Otwarcie się na świat z jasnościq i bez lęku stanowi czqstkę powołania chrześcijanina, świadomego własnej tożsamości i zakorzenionego w swojej religijnej spuściźnie, która wyraża bogactwo świadectwa Kościola ${ }^{35}$.

Na ten niekonfrontacyjny rys papieskiego podejścia do muzułmanów już u początków jego pontyfikatu zwrócila uwage Lucie Provost. W jej odbiorze znaczące było sięgnięcie przez papieża do biblijnego tekstu z Pierwszego Listu św. Piotra (1 P, 3, 15-16) w jego przemówieniu do chrześcijan w Ankarze w 1979 r. Nie ma w nim mowy o prozelityzmie, lecz o dialogu bazującym na świadectwie wiary w Chrystusa. Provost wskazała także na twórcze rozwijanie przez papieża wspomnianej już myśli o dialogu zawartej w Dekrecie Ad gentes (DM 11). W przemówieniu do przedstawicieli wspólnoty muzułmańskiej we Francji w 1980 r. Jan Paweł II stwierdził, że wspólnym ideałem jest braterskie społeczeństwo, którego czlonkowie starają się prześcigać nawzajem w czynieniu dobra. Provost słyszy w tym ujęciu echo także wspomnianej już koranicznej sury $(5: 48)^{36}$.

Ujęte we wprowadzeniu do niniejszego artykułu stwierdzenie, że Kościół przez długi czas aktywnie współuczestniczył w tworzeniu wrogiego muzułmanom nastawienia, nie oznacza wcale dyskredytacji przyjaznych gestów okazy-

32 Tamże.

${ }^{33}$ Zob. np. http://www.opoka.org.pl/aktualnosci/news.php?id=5467\&s=0poka otworzona 28 marca 2003 r. Także: http:/infocatho.cef.fr/fichiers html/archives/deuxmilletroissem/semai.../23nx07asiec.htm otworzona 17 lutego $2003 \mathrm{r}$.

${ }^{34}$ S. P. Huntington: Zderzenie cywilizacji, dz. cyt., s. 16

${ }^{35}$ Jan Paweł II: Homilia na stadionie Abbasydów w Damaszku,6 maja 2001 r. „Wiadomo ści KAI" (13 maja 2001) s. 32.

${ }^{36}$ L. Provost: From Tolerance to Spiritual Emulation. An Analysis of Official Texts on Christian-Muslim Dialogue. W: R. Rousseau (ed.): Christianity and Islam. Scranton 1985 s. 209. 
wanych przez jego członków. Ma ono na celu jedynie uwrażliwienie czytelników na istnienie w naszych czasach, niekiedy ukrytych, pozostałości tamtego nastawienia $^{37}$. Przykładów życzliwości, wzajemnego szacunku i współpracy między chrześcijanami i muzulmanami jest wiele. Sa one jednak przemieszane z przejawami wrogości i tendencjami do jej podsycania. Przykładem tych ostatnich nie sa jedynie odległe czasy krucjat czy narastającej nietolerancji w okresie po ukończeniu rekonkwisty, ale także np. działania chrześcijańskich misjonarzy w Afryce w XIX i XX w. Potrafili oni skutecznie podsycać obawy francuskiej administracji kolonialnej przed „muzułmańskim zagrożeniem” w północnej i zachodniej Afryce według zasady: „wszystko, co służy rozwojowi pracy misyjnej jest dobre, a to, co ją hamuje lub niszczy jest złe". Złączenie działalności misyjnej, pojmowanej jako zbawianie dusz i zakładanie Kościoła, z kolonializmem wpłynęło negatywnie na percepcję islamu przez chrześcijańskich misjonarzy. Upatrywano w nim pełnego zlych intencji konkurenta. Tak jak muzułmanie w Afryce Północnej wrogo odnosili się do przybyłych chrześcijańskich misjonarzy, tak ci ostatni wrogo patrzyli na „ekspansje” islamu w Afryce na południe od Sahary. Nie ulega watpliwości, że oba procesy zostały umożliwione przez europejską kolonizację, która zupełnie zmieniła istniejący układ sił politycznych ${ }^{38}$. Echa tej wrogiej postawy wciąż dają o sobie znać we współczesnych obawach przed rzekomą ekspansją islamu. Wyrażają je chrześcijańscy duchowni w Afryce i Europie $^{39}$. Pobrzmiewa ona także w nagłaśnianiu - jak w tekście Bölschego wypowiedzi muzułmanów, którzy rzekomo tylko czekają na sposobną chwilę, by „osłabionych dialogiem” chrześcijan zdominować i nad nimi zapanować ${ }^{40}$. Tej

${ }^{37}$ W niektórych katolickich liturgicznych świętach brzmią echa zwycięstw nad armiami postrzeganymi jako muzułmańskie, np. wspomnienie Najświętszej Maryi Panny Różańcowej - 7 października - upamiętnia zwycięstwo nad Turkami pod Lepanto w 1571 r. Zwycięstwo miało być wyproszone modlitwą różańcową.

${ }^{38}$ W 1938 r. przełożony generalny Misjonarzy Afryki (PA), o. Birraux w sprawozdaniu z podróży napisal: »je dois m'avouer inquiet des progrès réalisés par I'islam en AOF, sous le regard beinveillant de la France (...) un gouvernement européen va contre son interêt en favouriant l'islam dans un pays neuf, tandis qu'il travaille pour lui en soutenant le christianisme. Pousser des tribus entières vers l'islam, c'est les affilier à la civilisation et la mentalité orientales qui son partout anti-européennes « (...). Les Pères sont persuadés qu'en évangélisant les territoires à eux confiés, ils travaillent aussi à étendre l'influence de la France. Ils parlent volontiers du musulman comme d'un individu fanatique, auquel ils reprochent d'être xénophobe (P. Paulliat: Les Pères Blancs en Haute-Volta 1900-1960. W: G. Massa, Y. G. Madiéga [eds.]: La Haute-Volta coloniale. Paryż 1995 s. $197-198$ ).

${ }^{39}$ Zob. np. Togo: Kośció1 zaniepokojony ekspansja islamu. „Wiadomości KAI” (26 sierpnia 2001) s. 27; Cardinal Biffi returns to the attack. „The Tablet” (7 October 2000) s. 1345. Troche inaczej wygląda sprawa, gdy okazuje się, że przyczyną zmartwienia jest penetracja afrykańskich społeczności muzułmańskich przez ugrupowania fundamentalistyczne i zdobywanie przez nie wpływów (zob. np. otworzoną 2 marca 2003 r. stronę:

http://infocatho.cef.fr/fichiers html/archives/deuxmilletroissem/semain.../23nx09moa.htm

${ }^{40}$ J. Bölsche: Dialog zakłamany, dz. cyt., s. 9. 
ostatniej tendencji dali się chyba ponieść biskupi z wloskiego regionu Emilia Romagna, którzy w grudniu 2000 r. opublikowali dokument, ostrzegający chrześcijan przed zawieraniem mieszanych małżeństw i zarzucali muzułmanom brak tolerancji religijnej ${ }^{41}$. Zapewne $\mathrm{z}$ potępieniem $\mathrm{z}$ ich strony spotkał się także inny włoski biskup Giacomo Capuzzi z Lodi, który stwierdził: Pozwólcie im [muzutmanom] przyjechać do Whoch. Ich zamiar propagacji islamu jest także ich prawem, jak prawem nas chrześcijan jest głoszenie Chrystusa po całym świecie ${ }^{42}$. Powraca tu zatem problem misyjnej działalności. Jednak, jak stwierdza Eric Manhaeghe, misjonarz ze Zgromadzenia Niepokalanego Serca Maryi z Scheut, celem obecności chrześcijańskich misjonarzy w krajach muzulmańskich nie ma być prozelityzm, ale pełne miłości do Boga i człowieka służenie wszystkim. W krajach muzułmańskich misjonarz zostaje niejako wyzwolony z bycia przedstawicielem instytucji, która - jak każda inna instytucja - stawia na pierwszym miejscu własne interesy, by przyjmować nastawienie z jakim do wszystkich ludzi podchodzi Bóg. Manhaeghe stwierdza: Kościół nie istnieje dla siebie - jest $w$ służbie ludzkości i stwarza okazje, by wszyscy mogli spotkać uczniów Chrystusa w nadziei, że przez nich spotkajq samego Pana ${ }^{43}$.

Ignorancja, wzajemne niezrozumienie i uprzedzenia, przypisywanie sobie nawzajem wrogich zamiarów, chęć dominacji i wiele innych czynników wciagga nieustannie chrześcijan i muzułmanów w błędne koło powrotu do konfliktów. Okazuje się jednak, że nawet krwawe zderzenia mogą wyzwolić w czlonkach obu wspólnot wierzących konkretne dążenia do wychodzenia ponad ograniczenia i budowania pokoju. Właściwie pojęty dialog międzyreligijny staje się szansą wyrwania się z błędnego koła powrotu do konfliktów. Daje też okazję do oczyszczania i pogłębiania własnej wiary oraz sposobów jej wyrażania, aby stawać się dla siebie nawzajem czytelniejszym znakiem obecności Boga.

\footnotetext{
41 „Wiadomości KAI” (21 grudnia 2000) s. 38.

42 "The Tablet" (21 October 2000) s. 1427.

${ }^{43}$ E. Manhaeghe: Postawa misyjna chrześcijan w spotkaniu z muzułmanami. „Nurt SVD”. R. 1996 nr 2 (73) s. $29-46$.
} 